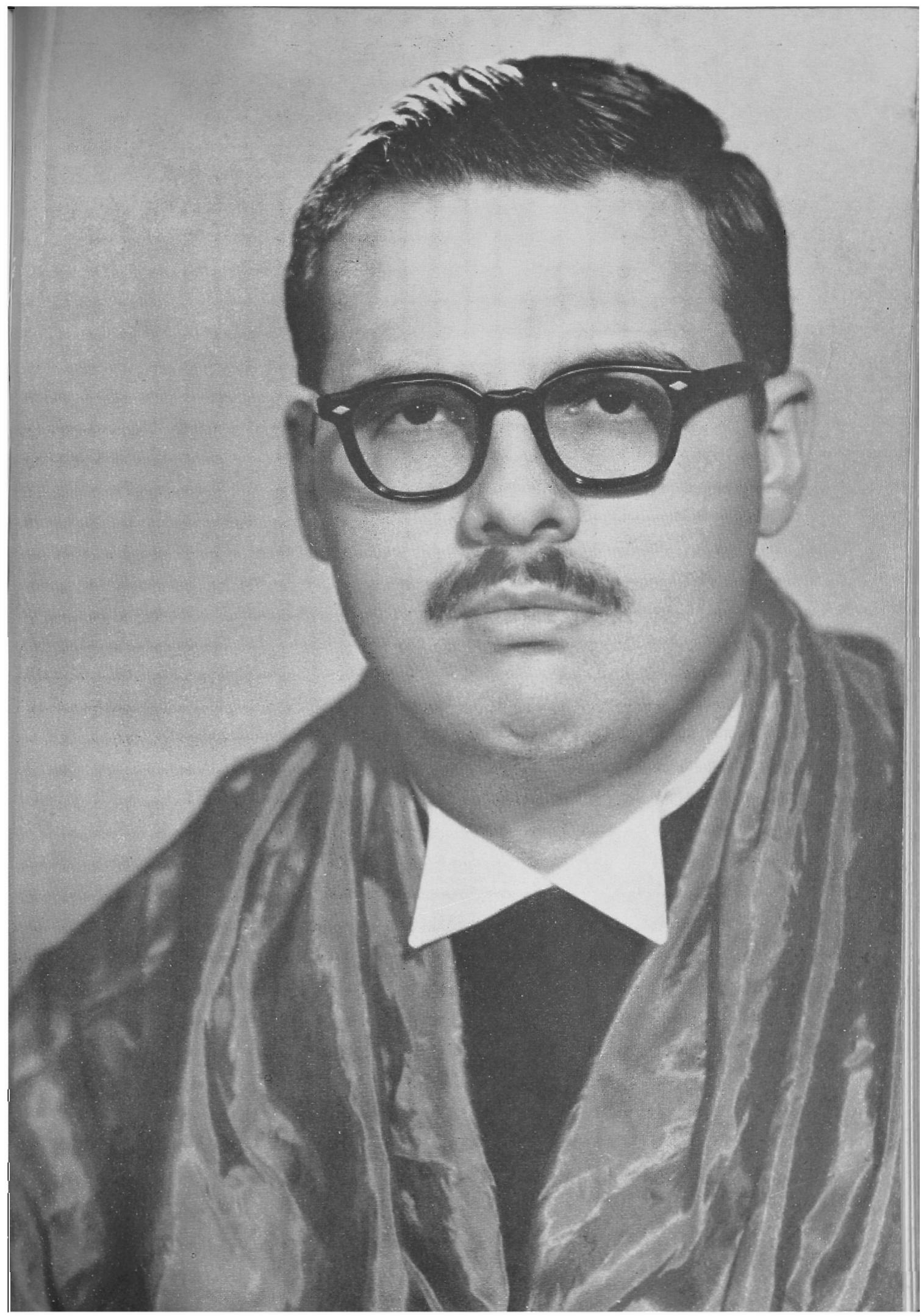


PROF. DR. JOS'É CARLOS MOREIRA ALVES Nôvo Catedrático de Direito Civil 


\section{Prof. Dr. José Carlos Moreira Alves, novo Catedrático de Direito Civil.}

O novo catedrático de Direito Civil, Prof. Dr. José Carlos Moreira Alves, nasceu em Taubaté, estado de São Paulo, aos 19 de abril de 1933; é filho de Luiz de Oliveira Alves e de D. Maria Ismênia Moreira Alves.

Fêz os cursos ginasial e científico, no Instituto Lafayette do Rio de Janeiro, de 1944 a 1950, tendo sido o primeiro aluno de suas turmas.

Aos 22 anos bacharelou-se pela Faculdade Nacional de Direito, do Rio de Janeiro, obtendo sempre o primeiro lugar. Ainda acadêmico foi laureado com o prêmio "Altolfo Rezende" relativo a 1955, conferido pelo Instituto dos Advogados Brasileiros.

Após o curso de doutorado na secção de Direito Privado, e defesa de tese, obteve o doutoramento, em 1961, pela Faculdade Nacional de Direito do Rio.

Iniciou a carreira docente universitária em 1957, como professor regente de Direito Civil e de Direito Romano, na Faculdade de Ciências Jurídicas do Rio de Janeiro. A contar dêsse ano lecionou sempre Direito Civil, Judiciário Civil e Romano, como Regente ou Professor Contratado na Faculdade de Direito da Pontificia Universidade Católica, na de Ciências Jurídicas do Rio de Janeiro e na Faculdade de Direito Cândido Mendes. Desde 1961, é livre docente de Direito Civil e Romano da Universidade Federal do Rio de Janeiro, onde, em 1968, foi nomeado catedrático interino daquela cadeira. 
Em 1961 submeteu-se a concurso de Direito Romano nesta Faculdade obtendo, brilhantemente, o segundo lugar que lhe outorgou a livre docência da cátedra.

Além de professor é advogado do Banco do Brasil S.A.; foi advogado militante no Rio de Janeiro onde faz parte da Diretoria do Instituto dos Advogados Brasileiros, do qual é membro desde 1959.

Em setembro de 1967, como um dos quatro representantes do mesmo Instituto, esteve na Argentina a convite do Embaixador da Argentina no Brasil, em missâo cultural.

Com tal experiência docente, jurídica e cultural e a rica matéria bibliográfica apresentada, obteve, em 1968, com a média global 9,575, o primeiro lugar no concurso para a cátedra de Direito Civil, na qual se empossou no mesmo ano, integrando desde então a Congregação de Professôres desta Faculdade.

\section{Bibliografia.}

\section{A) Direito Civil Romano:}

1. Direito Romano, $1 .^{\circ}$ volume - (História do Direito Romano - Instituições de Direito Romano: A) - Parte Geral; B)

- Parte Especial: Direito das Coisas), 403 p., Editor Borsoi, Rio de Janeiro, 1965; 2. ${ }^{\mathrm{a}}$ ed., 1967.

2. Direito Romano, $2 .^{\circ}$ volume (Instituições de Direito Romano: B) - Parte Especial: Direito dows Obrigações; direito de família; direito das sucessões), 611 p., Editor Borsoi, Rio de Janeiro, 1966.

3. Tertiis'Mundinis Partis Secanto, 56 págs., Rio de Janeiro, 1958.

4. Os Efeitos da Boa Fé no Casamento Nulo, segundo o Direito Romano, 51 págs., Rio de Janeiro, 1959.

5. A Forma Humana no Direito Romano, 77 págs., Rio de Janeiro, 1960.

6. Vnus Casus (Inst. IV, 6, 2), 56 págs., Rio de Janeiro, 1964; reeditado na "Revista Verbum" da PUC do Rio de Janeiro, fasc. - setembro/dezembro de 1967. 
B) De Direito Civil Brasileiro:

1. A Retrovenda, 294 págs., Editor Borsoi, Rio de Janeiro, 1967.

2. O Atual Projeto de Código Civil Brasileiro, publicado em SPSE (órgão oficial do Instituto de Estudos Políticos e Sociais da Pontifícia Universidade Católica do Rio de Janeiro), n. ${ }^{\circ} 30$ (abril-junho de 1966), p. 49 a 79.

3. A Evolução da Teoria do Casamento Inexistente, publicado na "Revista Verbum", da Pontifícia Universidade Católica do Rio de Janeiro, tomo XXX, fasc. 4 (ano de 1963), p. 419 a 438.

4. Ocupação, publicado no "Repertório Enciclopédico do Direito Brasileiro", vol. 35, págs. 113 a 116.

5. Outorga Marital, publicado no "Repertório Enciclopédico do Direito Brasileiro", vol. 35, págs. 337 a 339.

6. Outorga uxória, publicàdo no "Repertório Enciclopédico do do Direito Brasileiro", vol. 35, págs. 339 a 341.

7 Perda da posse, publicado no "Repertório Enciclopédico do Direito Brasileiro", vol. 37, págs. 10 a 14.

8. Perda da Propriedade, publicado no "Repertório Enciclopédico do Direito Brasileiro", vol. 37, págs. 14 a 18.

C) Outros Trabalhos:

1. Direito Romano e Ensino Jurídico, 24 págs., Irmãos Pongetti Editôres, Rio de Janeiro, 1962.

2. Oração de Paraninfo, publicada no "Jornal do Comércio" do Rio de Janeiro, de 24 de dezembro de 1966, pág. 9.

3. Sallustius et Fausta, artigo escrito em latim, publicado na "Revista Verbum" da Pontifícia Universidade Católica do Rio de Janeiro, tomo XX, fasc. 3, ano de 1963, págs. 329 a 334. 